\title{
Local Election in 2017 in Indonesia: Test of Tendencies to Abuse Grant Expenditure and Social Aid Expenditure Budget by Incumbent Candidates
}

\author{
Abdul Hafiz Tanjung*
}

\section{ค OPEN}

\section{AFFILIATION:}

Department of Accounting, Faculty of Economics, Universitas Nasional PASIM, West Java, Indonesia

\section{*CORRESPONDENCE:}

hafiztanjung1970@gmail.com

THIS ARTICLE IS AVAILABLE IN: http://journal.umy.ac.id/index.php/ai

DOI: 10.18196/jai.2102153

\section{CITATION:}

Tanjung, A. H. (2020). Local Election on 2017 in Indonesia: Test of Tendencies to Abuse Grant Expenditure and Social Aids Expenditure Budget By Incumbent Candidates. Journal of Accounting and Investment, 21(2), 346-361.

\section{ARTICLE HISTORY}

Received:

10 January 2020

Reviewed:

7 May 2020

Revised:

11 May 2020

Accepted:

12 May 2020
Abstract:

Research aims: This research was conducted and aimed to examine the tendencies to abuse the power of incumbent candidates in making budget of grant expenditure and social aid expenditure to support their political interests in the local election on February 15th, 2017, in Indonesia.

Design/Methodology/Approach: There were two populations in this study, namely the first population of district/municipality areas that carried out the elections, which included incumbent candidates in size of 53

districts/municipalities, and the population of both district/municipal regions that carried out the elections, which had no incumbent candidates in size of 41 districts/municipalities. Samples were chosen by cluster random sampling with proportional allocation between districts and municipals. The sample for the first population was 35 districts/municipalities, consisting of 26 districts and nine municipalities, while the sample for the second population was 29 districts/municipalities, consisting of 25 districts and four municipalities. Two statistical analyses were employed in this research; parametric statistics, i.e., paired t-test, independent t-test variances unknown but equal, and the nonparametric statistics, i.e., Mann-Whitney $U$ test and Wilcoxon test. Data normality test using w/s test had been done to determine which analysis to be used.

Research findings: The result of this research showed that there was empirical evidence of tendencies to abuse incumbent candidates' power in making budget of grant expenditure and social aid expenditure to support their political interests in the local election on February 15th, 2017.

Theoretical contribution/Originality: This study's results reinforce that the incumbent regional head has more authority in budget management, especially during local government head of elections.

Practitioner/Policy implication: Based on the findings, the central government needs to change the rules on the use of grant expenditure and social aid expenditure on local governments from indirect expenditure to direct expenditure that can be measured by performance.

Research limitation/Implication: This study has a limitation that lies in grant expenditure, and social aid expenditure studied, which only looked at the increase or decrease in the number of realization of grant expenditure and social aid expenditure in the local government budget realization report, not on the effectiveness of its distribution.

Keywords: Grant Expenditure; Social Aid Expenditure; Local Election 
Local Election in 2017 in Indonesia: Test of Tendencies to Abuse Grant Expenditure ...

\section{Introduction}

In the running of the constitution of the Republic of Indonesia No. 8 in the year of 2015, it is said that the regional local elections are held every five years in the Republic of Indonesia in the same period. On Wednesday, February 15th, 2017, the direct election of regional heads in the second wave in 76 districts and 18 municipalities throughout Indonesia was held simultaneously. The head of the region's election was followed by 236 candidates for district head and 50 candidates for mayor. There were 179 candidates for district head and 41 candidates for mayor, who were supported by the political party, and the others were nominated individually; at the time, there were 40 incumbent candidates for district head and 13 incumbent candidates for mayor (kpu.go.id, 2017).

After the 2017 local elections, simultaneous local elections were also held on June 27, 2018, in the third period of local elections, which were held in 115 districts and 39 municipals in Indonesia. Soon, simultaneous local elections will be held on September 23, 2020, and will be followed by 224 districts and 37 municipals in Indonesia. However, according to Ade Irawan, coordinator of Indonesia Corruption Watch, he said that ahead of the election, there was a tendency to make local government budget in social aid expenditure and grant expenditure. Those budgets were used to support the incumbent won in the election, especially if the budget could be planned 50 to 100 percent compared to the last budget before (Kompas.com, 2016). According to Sjahrir, Kis-Katos, and Schulze (2013), the incumbent candidate had more authority in budgeting (planning, implementing, and reporting) to be used for the political interests of the incumbent candidates. Harsasto (2014) stated that the involvement of regional heads in the implementation of the budget strengthened during the regional head election. The incumbent candidates' opportunity to utilize grant expenditure and social aid expenditure are due to authorization of the expenditure carried out by the head of the region himself so that the funds tend to be used for the incumbent candidate's political interests. Hessami (2013) cited that politicians had much more power to distort (deviate) public resources; those distortions caused the government to fail in fulfilling its purpose.

Ritonga and Alam (2010) said that when incumbent being nominated as a candidate in the re-election, the incumbent had an opportunity and tendency to politicize local government budgets to support their political objectives. In this case, the regulation of the Ministry of Home Affairs No. 32 in the year of 2011 states that grant expenditure and social aid expenditure belong to special programs that cannot be seen by job target planning so that it also tends to be done subjectively.

Empirical research showed that proportional budget in grant expenditure was a much bigger proportion in the regions of incumbent candidates at the period of the election compared to before the election (Ritonga \& Alam, 2010; Amalia \& Pratolo, 2013), as well as in the case of social aid expenditure (Amalia \& Pratolo, 2013). The empiric research also indicated that the proportional budget in grant expenditure and social aid expenditure was much higher in proportion in the regions of incumbent candidates than 
non-incumbent candidates during the election (Ritonga \& Alam, 2010). However, not all empirical research results revealed the same findings. The empirical research results also showed no increase or difference in the proportion of grant expenditure in the incumbents' regions at the period of election compared to the period before the election (Winoto \& Falikhatun, 2015; Suranta \& Pangarso, 2015), as well as for social aid expenditure (Winoto \& Falikhatun, 2015).

According to the new regulation of the Ministry of Home Affairs No. 39 in the year of 2012 , the budgeting of grant expenditure and social aid expenditure does not belong to one package (see regulation of Ministry of Home Affair no. 23 in the year of 2011), the receiver, address, and the sum-up of social aid grants must be registered or reported to the government. On the contrary, if it is not done, it can be considered as an abuse of power, which has tendencies to political money while the regional local elections are going to be done.

Based on the phenomenon above, the aims of the research on simultaneous direct election of regional heads held on February $15^{\text {th }}, 2017$ were to determine the difference of mean on grant expenditure and social aid expenditure in the regions of incumbent candidates and non-incumbent candidates, and also on a tendency to corrupt the local government budget to support their goals in politics. The aim was to see possible indications of misuse of grant expenditure and social aid expenditure for incumbent pairs' private interests in the simultaneous local elections in 2017. Meanwhile, the existence of the Regulation of Minister of Home Affairs Number 32 in the year of 2011, which related to Regulation of Minister of Home Affairs Number 39 in the year of 2012, requires the results of empirical studies in its implementation. The results of this study are expected to provide evaluation material in the improvement of regulations in the next period, particularly in budgeting and channeling of grants and social aids to local governments in Indonesia. Meanwhile, the difference between this research and previous research lies in the local election, which was used as a research case; the previous research took the local election before 2017 as a research case, while the researcher took the research case from the elections on February $15^{\text {th }}, 2017$. Therefore, the object of study was the districts and municipalities that carried out the elections, thus making a difference between the current researcher and previous researchers.

\section{Literature Review and Hypotheses Development}

\section{Definition of Regional Revenue and Expenditures Budget (APBD)}

In the regulation of the Minister of Home Affairs No. 52 in the year of 2015, the guidance of arrangement (APBD) year 2016 in Chapter 1 states about the budgeting of money and expenditure on local government. It is named APBD, which means the planning of budgeting. APBD is discussed, approved, and agreed by Regional People's Representative Assembly. 
Local Election in 2017 in Indonesia: Test of Tendencies to Abuse Grant Expenditure ...

\section{Grant Expenditure}

In the regulation of Minister of Home Affairs No. 32 in 2011, the guidance of grant expenditure and social expenditure is sourced from the money budgeting and expenditure. The regulation also defines the grant. A grant expenditure is the given money, things, and services from government to government, government to the organization, government to the institution, and it is also explicitly regulated. Moreover, it cannot be guaranteed and ruled and primarily also support the running of local government programs.

In the regulation of Minister of Home Affairs No. 13 in the year of 2006 about the guidance of regional budgeting of money on Chapter 37, it is said that grant expenditure belongs to indirect spending that is guided and declared in chapter 36 . It is budgeted into the indirect program and activities of the regional government. Grant expenditure in the regulation of Minister of Home Affairs No. 32 in the year of 2011 at Chapter 4 was cleared that at least, the aims of spending must be written and guided; before it was not a must, it was not binding, and it did not run continuously, and the receiver must have fulfilled the requirements.

Furthermore, in the regulation of Minister of Home Affairs No. 392012 about the amendment of the regulation of Minister of Home Affair No. 32 in the year of 2011 on Chapter 11, it is said that grant of money is budgeted into indirect expenditure, kind of expenditure and object expenditure on the manager of regional monetary. The expenditure of things or services is formulated into programs and activities that known and agreed by the regional authority.

\section{Social Aid Expenditure}

According to the regulation of the Minister of Home Affair No. 32 in the year of 2011, social aid expenditure is that the government provides some money or things to individual, family, organization, or group of people, and it is not continuously; moreover, it has a function to protect from social risk. As with grant expenditure, the regulation of the Minister of Home Affairs No. 13 in the year 2006 article 37 states that social aid expenditure includes an indirect expenditure portion, which is budgeted expenditure that is not directly related to the implementation of programs and activities. According to the regulation of the Minister of Home Affair No. 32 in the year of 2011 on Chapter 24, social aid expenditure must have requirements such as:

a. Selective; social aid expenditure is given to the people who have the possibility of social risk.

b. Fulfilled out the requirements of social aid expenditure. It is aimed at a person who has an identity and lives in one region.

c. It is not continuous, and it means that it does not need to be budgeted annually.

d. Supports the aim of social aids, such as social rehabilitation, social security, social development of ability, social guarantee, social economy, and disaster. 
Local Election in 2017 in Indonesia: Test of Tendencies to Abuse Grant Expenditure ...

\section{Local Government and The Election}

In the constitution of the Republic of Indonesia No. 23 in the year of 2014 about regional government, it says that regional government is the ruler and doer of all the businesses in the government by the head/mayor, governor, and the regional people assembly based on local autonomy. It belongs to the guidance of the 1945 Constitution of the Republic of Indonesia.

In the running of the regional government, it is based on the Republic of Indonesia Law No. 23 the Year 2014, Chapter 58, as follows:
a. Legal certainty,
b. Rules of the running government,
c. Public interest,
d. Open access,
e. Proportionality,
f. Professionality,
g. Accountability,
h. Efficiency,
i. Effectivity, and
j. Justice.

Every region is led by the head of local government, such as governor who manages the province, a regent who manages the district, and a mayor who manages the municipal. The running of their programs is limited by the time at least five years after their inauguration, and they can be re-nominated after five years period (In the Republic of Indonesia Law No. 23 in the year of 2014). The regional election of the governor and vice governor, head of district and vice head, the mayor and vice mayor is elected by the people directly and democratically (in the Republic of Indonesia Law No. 8 in the year of 2015); furthermore, in Chapter 3 as stated in the Law, those elections are held in every five years simultaneously in every region in the Republic of Indonesia.

\section{Legitimation Theory}

The regional election, which is done by the people to get the legitimation of their mayor or head of the regional government, is a form of sovereignty of the people. The election aims to get a regional head that has legitimation in people's views. According to Suchman (1995), the public perceptions of one entity that they have an obligation to do regional election, and it is suitable with the social system. The election is built by norms, values, and beliefs, or faith. According to Fatoni (2006), the legitimation can be interpreted as a claim and willingness of people to accept their mayor or head to run the government. The way to get legitimation is, for example: first, symbolism is the one of morality, emotion, tradition as well as faith and the formal ceremony of the country. The second one, instrumental, is the promise to give basic needs of the people such as food, education, health, etc., and the third one, regional election, is done to get a much better policy in their governmental. In the applied theory, the legitimation can be seen in the 
Local Election in 2017 in Indonesia: Test of Tendencies to Abuse Grant Expenditure ...

incumbent mayors and vice mayors; they are nominated or elected, and they usually tend to abuse power in the sector of grant expenditure and social aid expenditure.

\section{Indications of Misuse of Grant Expenditures}

Grant expenditure and social aid expenditure are activities that budgeted by mayor and head of local government, and their budgeting must be done as the regulation of the Minister of Home Affairs No. 32 in the year of 2011. Mardiasmo (2009) said that budgeting is one a difficult step in the public sector, and tends to have political nuance. Planning, implementing, and reporting must be controlled. Rubin (2017) states that public budgeting does not only involve technical and managerial processes but also includes the political process; therefore, the budget reflects the level of importance that regulators have in satisfying their constituents and responding to the demands of interest groups. This grant expenditure in APBD is budgeted in indirect expenditure, which is an expenditure that is not directly related to local government programs and activities (see the regulation of the Minister of Home Affair No. 32 in the year of 2011 and the regulation of the Minister of Home Affair No. 13 in the year of 2006). Thus, this grant expenditure can be used by incumbent pairs to attract the hearts of the people in getting votes (Ritonga \& Alam, 2010). Moreover, the authorization of the use of grant expenditure is at the head of the region, making the grant expenditure prone to be used by incumbent pairs for political interests (Harsasto, 2014).

The previous research result showed an indication that the incumbent candidate planned grant expenditure budgeting, and it tended to budget a bigger proportion of grant expenditure than those before the period of election (Ritonga \& Alam, 2010; Amalia \& Pratolo, 2013; Sjahrir et al., 2013). Based on the literature above and arguments discussed in the previous section, the study's proposed first hypothesis is as follows:

$H_{1}$ : Mean of grant expenditure in incumbent candidates' local government budget at the period of the election is bigger than before the period of the election.

\section{Indications of Misuse of Social Aids Expenditure}

Elections are one way to gain legitimacy by incumbent pairs and non-incumbent pairs (Fatoni, 2006). In order to win the incumbent candidate's election, social aid expenditure is used to win the hearts of the people in getting votes (Ritonga \& Alam, 2010). It can happen because the social aid expenditure budget is planned for indirect expenditure, which is not directly related to the programs and activities of the regional government (see the regulation of the Minister of Home Affair No. 32 in the year of 2011 and the regulation of the Minister of Home Affair No. 13 in the year of 2006). Besides, according to Harsasto (2014), the authorization of the use of social aid expenditure is at the regional head; if the regional head is an incumbent candidate, it makes the social aid expenditure prone to be used for his/her political interests. 
The results of previous studies showed that there were indications of the utilization of social aid expenditure funds by the incumbent candidates' APBD, seen from the proportion of social aid expenditure implementation at the time of the election compared to the proportion of social aids expenditure before the election (Amalia \& Pratolo, 2013; Sjahrir et al., 2013). Based on the explanation, the study's proposed second hypothesis is as follows:

$\mathrm{H}_{2}$ : The mean of social aid expenditure in incumbent candidates' local government budget at the time of the election is bigger than before the period of the election.

\section{Indications of Misuse of Grant Expenditures and Social Aids Expenditures in Incumbent Regions compared to Non-Incumbent Regions}

Many regions in Indonesia participated in the 2017 elections. Among the regions participating in the elections, there were areas where the incumbent candidates were re-nominated again, and there were also regions where there were no incumbent candidates re-nominated again. In regions where there were no re-nominated incumbent candidates, the regional head in charge had no political interests in the election year, while the non-incumbent candidate pairs had no authority to regulate the use of the grant expenditure and social aids expenditure. In regions where incumbent candidates were re-nominated again, incumbent candidates could use the authority to use the grant expenditure and social aid expenditure that was available for political purposes so that they could be re-elected. Sjahrir et al. (2013) said that the incumbent candidates had more authority in budgeting arrangements so that the budget could be utilized for the personal interests of the relevant candidate pairs.

The result of empiric research showed that the proportion of grant expenditure and social aid expenditure was much bigger in regions of incumbent candidates than those in non-incumbent candidates during the elections (Ritonga \& Alam, 2010; Sjahrir et al., 2013). Based on the explanation above, two hypotheses can be formed as follows:

$\boldsymbol{H}_{3}$ : The mean of grant expenditure in incumbent candidates' local government budget is bigger than that of non-incumbent candidates during the elections.

$\boldsymbol{H}_{4}$ : The mean of social aid expenditure in incumbent candidates' local government budget is bigger than that of non-incumbent candidates during the election.

\section{Research Method}

\section{Research Design}

The descriptive method and comparative method approach were used in this research. The descriptive method was employed to describe statistically grant expenditure and social aid expenditure at the regional places that participated in the local election in 
Local Election in 2017 in Indonesia: Test of Tendencies to Abuse Grant Expenditure ...

2017. Meanwhile, the comparative method was done to examine the mean of difference of grant expenditure and social aid expenditure between regions of incumbent candidates in the period of the election with before the period of election, as well as to examine the mean of difference of grant expenditure and social aid expenditure between regions of incumbent candidates with regions of non-incumbent candidates in the period of the election.

\section{Operational Definitions and Measurement of Variables}

There were two variables in this research, namely, grant expenditure and social aid expenditure. Each of these variables is defined as shown in the following table:

Table 1 Definition of Operational Variables

\begin{tabular}{lll}
\hline \multicolumn{1}{c}{ Variable } & \multicolumn{1}{c}{ Definition } & Scale \\
\hline Expenditure & $\begin{array}{l}\text { The giving of money/goods or services from the regional government } \\
\text { to the government or other regional governments, regional } \\
\text { companies, communities, and community organizations, which has } \\
\text { been specifically designated as intended, is not mandatory, is not } \\
\text { binding, and is not continuously, aimed at supporting the } \\
\text { implementation of regional government affairs (Regulation of the }\end{array}$ \\
$\begin{array}{l}\text { Minister of Home Affairs No. } 32 \text { in the year of 2011). } \\
\text { Expenditure Aids }\end{array}$ & $\begin{array}{l}\text { Provision of assistance in the form of money/goods from local } \\
\text { governments to individuals, families, groups, and/or communities } \\
\text { that are not continuous and selective in nature and it aims to protect } \\
\text { against the possibility of social risks (Regulation of the Minister of } \\
\text { Home Affairs No. 32 in the year of 2011). }\end{array}$ \\
\hline
\end{tabular}

\section{Population and Samples}

The local government of districts and municipals that followed the simultaneous direct election of regional heads in 2017 were as many as 94 regionals; there were 76 districts and 18 municipals. They were grouped into two populations. The first population was incumbent candidates from 53 regionals ( 40 districts and 13 municipals). The second population was non-incumbent candidates from 41 regionals (36 districts and five municipals). The population of this study consisted of two populations because, in this study, a different test of the mean of grant expenditure and the mean of social aid expenditure at the time of the election were compared to before the election in areas with incumbent candidates. Besides that, a different test of the mean of grant expenditure and the mean of social aid expenditure were also carried out during the implementation of the elections between regions with incumbent candidates and regions without incumbent candidates.

The size of each sample employed the formula from Yamane (1967) with a precision value of $10 \%$. Then, the sampling technique used was stratified random sampling with a proportional allocation of each district and municipal to have a representative in sample research. Thus, the size of the sample of the first population was 35 regions, which was divided into 26 districts and nine municipals. Whereas, the size of the sample of the 
Local Election in 2017 in Indonesia: Test of Tendencies to Abuse Grant Expenditure ...

second population was 29 regions, which was divided into 25 districts and four municipals.

\section{Data and Source of Data}

This research used secondary data. The first data was a total of districts and municipalities in Indonesia that followed the simultaneous direct election of regional heads in 2017, followed by incumbent and non-incumbent candidates (General Election Commissions, 2017). The second was grant expenditure and social aid expenditure in the realization report of local government budget in Indonesia for the period of 2015 and 2016 (Directorate General of Fiscal Balance Ministry of Finance of Republic of Indonesia, 2017). The fiscal year of 2016 was used as data for grant expenditure and social aid expenditure at the period of the simultaneous election. It was done because the fiscal year of 2017, when simultaneous election being done on February $15^{\text {th }}, 2017$, has not yet fully implemented, while the fiscal year of 2015 was used as data for grant expenditure and social aid expenditure before the event of a simultaneous election.

\section{Analysis Method}

All hypotheses were examined at $95 \%$ significant level. The testing technique used for hypothesis 1 was paired t-test, cited from Soedibjo (2013). Before that, the testing of data normality had been carried out to get assumption data of distribution data both for 2015 data and 2016 data. The results showed that the data distribution was not normal. In this case, the researcher transformed the data into logarithm $y 1=\log (x 1)$ and was retested, and then, the result showed that the distribution of data was normal. Hypothesis 2 and hypothesis 3 used the Wilcoxon test, which was cited from Soedibjo (2013). It was performed after the testing of data normality, which showed that the distribution of data was not normal.

Furthermore, hypothesis 4 was examined by independent t-test variances unknown but equal. It was cited from Soedibjo (2013). Previously, the testing of variance similarity had been done that showed the result of equal variant and also had been tested the data normality both for grant expenditure of incumbent candidates and grant expenditure of non-incumbent candidates, which was initially not normally distributed. First, the researcher did the transformation to logarithm form, then it was re-tested, and the result showed a normally distributed data.

However, for hypotheses 5 and 6, the statistical test used was a Mann-Whitney $U$ test, which was cited from Siegel (1956). It was employed after testing data normality, which showed that grant expenditure and social aid expenditure on incumbent and nonincumbent candidates were not normal.

The data normality testing of grant expenditure and social aid expenditure on incumbent candidates (in the year of 2015 and 2016) as well on non-incumbent candidates (in the year of 2016) used w/s test cited from Kanji (1993). 


\section{Results and Discussion}

\section{Grant Expenditures in Incumbent Candidate Areas: Descriptive Analysis and Hypothesis Testing Results 1}

The average of grant expenditure before the period of the election on 35 samples of incumbent candidates was Rp25.773.000.000,00 (the highest grant expenditure was Rp89.925.000.000,00, and the lowest was Rp0), while at the period of the election, the average of grant expenditure was Rp59.560.000.000,00 (the highest grant expenditure was Rp226.930.000.000,00, and the lowest was Rp15.649.000.000,00). It means that grant expenditure on 35 samples of incumbent candidates increased on average by Rp33.378.000.000,00 or $131,10 \%$ at the period of the election than before the period of the election.

Figure 1 illustrates grant expenditure on incumbent candidates in the period of election, and it was compared with before the period of election.

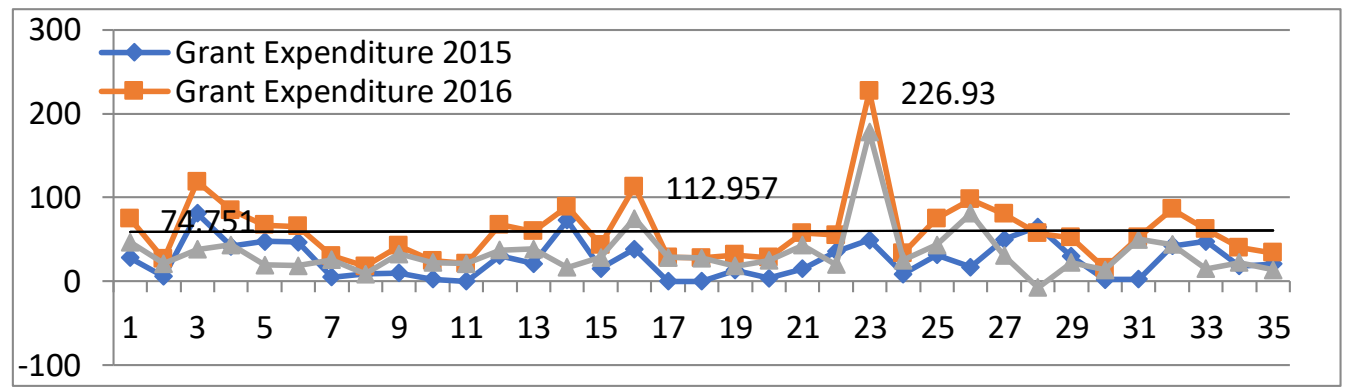

Figure 1 Grant Expenditure of Incumbent Candidates on 2015 and 2016 (in a million Rupiah) Source: Directorate General of Fiscal Balance Ministry of Finance of Republic of Indonesia, 2017 (processed).

Table 1 shows the increase of grant expenditure on 35 samples of incumbent candidates in 2016 compared to 2015.

Table 1 Increased of Grant Expenditure of Incumbent Candidates on 2016

\begin{tabular}{llcl}
\hline No & $\%$ Increase & Districts/municipals & \multicolumn{1}{c}{ Explanations } \\
\hline 1 & 0 to $\leq 50$ & 6 & 4 districts and 2 municipals \\
2 & $>50$ to $\leq 100$ & 5 & 2 districts and 3 municipals \\
3 & $>100$ to $\leq 200$ & 10 & 8 districts and 2 municipals \\
4 & $>200$ to $\leq 300$ & 2 & 2 districts \\
5 & $>300$ to $\leq 400$ & 3 & 3 districts \\
6 & $>400$ to $\leq 500$ & 1 & 1 district \\
7 & $>500$ to $\leq 1000$ & 3 & 2 districts and 1 municipal \\
8 & $>1000$ & 5 & 4 districts and 1 municipal \\
\hline Total & & 35 & \\
\hline Source & Directorate & \\
\hline
\end{tabular}

Source: Directorate General of Fiscal Balance Ministry of Finance of Republic of Indonesia, 2017 (processed). 
Local Election in 2017 in Indonesia: Test of Tendencies to Abuse Grant Expenditure ...

The result of hypothesis 1 was to examine the difference of the mean of grant expenditure at the period of election compared before the period of the election at regions of incumbent candidates, and it can be seen in Table 2 .

Table 2 Hypothesis Testing Result 1

\begin{tabular}{lllllll}
\hline Mean Log & GE 2016 & GE 2015 & Difference & t-count & t-table & Explanation \\
\hline $\begin{array}{l}\text { Grant } \\
\text { Expenditure }\end{array}$ & 4.69917 & 3.90326 & 0.795914 & 4.054 & 1.684 & ${\text { Accept } \mathrm{H}_{1}}$ \\
\hline
\end{tabular}

From the Table 2, the mean of grant expenditure at regions of incumbent candidates was bigger at the period of the election than before the period of the election. It means that incumbent candidates had a tendency to grant expenditure usage for their political interests in the simultaneous elections of 2017. This result is the same as previous research (Ritonga \& Alam, 2010; Amalia \& Pratolo, 2013; Sjahrir et al., 2013).

Social Aid Expenditure in Regions of Incumbent Candidates: Descriptive Analysis and Hypothesis 2 Testing Result

The average social aid expenditure before the period of the election on 35 samples of incumbent candidates was Rp14.061.000.000,00 (the highest social aid expenditure was Rp94.154.000.000,00, and the lowest was Rp0). Whereas, at the period of the election, the average social aid expenditure was Rp11.448.000.000,00 (the highest social aid expenditure was Rp98.746.000.000,00, and the lowest was Rp0). It means that social aid expenditure on incumbent candidates decreased. In general, all of the samples of incumbent candidates showed no meaningful increase in social aid expenditure.

Figure 2 illustrates social aid expenditure on incumbent candidates in the period of election, and it was compared to before the period of election.

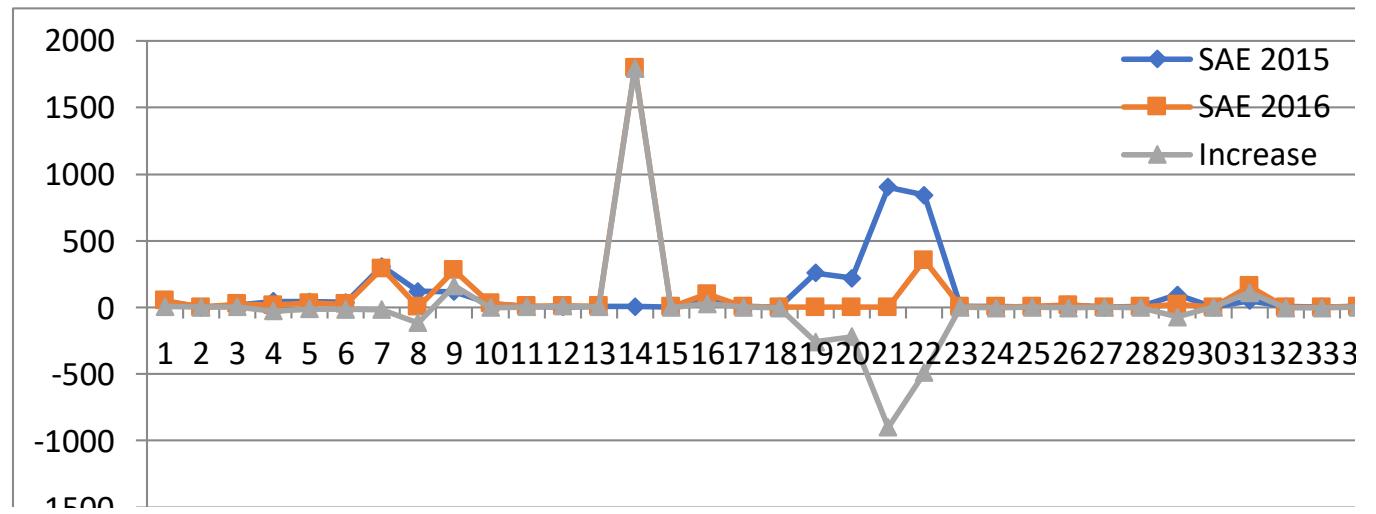

Figure 2 Social Aids Expenditure of Incumbent Candidates on 2015 and 2016 (in a million Rupiah)

Source: Directorate General of Fiscal Balance Ministry of Finance of Republic of Indonesia, 2017 (processed) 
It means that incumbent candidates did not utilized the social aid expenditure's advantage in the simultaneous elections of 2017. It is also shown from the result of examining the hypothesis 2 , as can be seen in Table 3 .

Table 3 Hypothesis Testing Result 2

\begin{tabular}{lccclll}
\hline Mean & 2016 & 2015 & Z-count & Probability & Level $\alpha$ & Explanation \\
\hline SAE & $11.448,49$ & $14.061,57$ & $-0,710$ & 0,2389 & 0,05 & Accept $\mathrm{H}_{0}$ \\
\hline
\end{tabular}

As seen from table 3 , the mean of social aid expenditure at regions of incumbent candidates at the period of the election was not bigger than before the period of the election. These research result are not the same as the previous research by Amalia and Pratolo (2013) and Sjahrir et al. (2013).

Comparison of Incumbent Areas' Grant Expenditure with Non-Incumbent Candidate Areas: Descriptive Analysis and Hypothesis 3 Testing Results

The average of grant expenditure from 35 samples on regions of incumbent candidates at the period of the election was Rp59.560.000.000,00 (the highest grant expenditure was Rp226.930.000.000,00, and the lowest was Rp15.649.000.000,00). Meanwhile, the average grant expenditure from 29 samples on regions of non-incumbent candidates at the period of the election was Rp40.932.000.000,00 (the biggest grant expenditure was Rp92.058.000.000,00, and the lowest was Rp18.679.000.000,00). It means that grant expenditure at 35 samples on regions of incumbent candidates was bigger on average by $\mathrm{Rp} 18.627 .000 .000,00$ or $45,51 \%$ than on 29 samples on regions of non-incumbent candidates at the period of the election.

Figure 3 illustrates grant expenditure on 35 samples on regions of incumbent candidates in the period of election, and it was compared to 29 samples on regions of nonincumbent candidates.

500,000

Figure 3 Grant Expenditure on Incumbent Candidates and Non-Incumbent Candidates at the Period of Election (In million Rupiah)

Source: Directorate General of Fiscal Balance of Republic of Indonesia Ministry of Finance, 2017 (processed) 
From Figure 3, it can be seen that the incumbent candidate's regional grant expenditure was greater than the non-incumbent candidate's regional grant expenditure at the time of the election. It can also be seen from the results of testing hypothesis 3 , as shown in Table 4.

Table 4 Hypothesis Testing Result 3

\begin{tabular}{lllllll}
\multicolumn{1}{c}{$\begin{array}{c}\text { Mean Log } \\
2016\end{array}$} & Incumbent & $\begin{array}{c}\text { Non- } \\
\text { incumbent }\end{array}$ & Difference & t-count & t-table & Explanation \\
\hline $\begin{array}{l}\text { Grant } \\
\text { Expenditure }\end{array}$ & 4.6992 & 4.5652 & 0.134 & 2.295 & 1.671 & Accept $\mathrm{H}_{1}$ \\
\hline
\end{tabular}

From Table 4, it can be observed statistically that the average incumbent candidate's regional grant expenditure was greater than the non-incumbent candidate's regional grant expenditure during the election. The results of this study reinforce the evidence of an indication of the use of grant expenditure by incumbent candidates for personal political interests during the 2017 elections. This study's results are in line with the results of the study (Ritonga \& Alam, 2010; Sjahrir et al., 2013).

Comparison of Incumbent Candidate's Regional Social Aid Expenditure with NonIncumbent Candidate Regions: Descriptive Analysis and Hypothesis 4 Testing Results

The average of social aid expenditure from 35 samples on regions of incumbent candidates at the period of the election was Rp11.448.000.000,00 (the highest social aid expenditure was Rp98.746.000.000,00, and the lowest was Rp0). In comparison, social aid expenditure from 29 samples on regions of non-incumbent at the period of the election was Rp5.596.970.000,00 (the highest social aid expenditure was Rp49.213.000.000,00, and the lowest was Rp0). It means that social aid expenditure at 35 samples on regions of incumbent candidates was bigger on average by Rp5.851.000.000,00 or $104,54 \%$ than at 29 samples on regions of non-incumbent candidates at the period of the election.

Figure 4 Social Aids Expenditure on Incumbent Candidates and Non-Incumbent Candidates at the Period of Election (in a million Rupiah)

Source: Directorate General of Fiscal Balance of Republic of Indonesia Ministry of Finance, 2017 (processed) 
As can be seen from Figure 4, it illustrates social aid expenditure from 35 samples on regions of incumbent candidates in the period of election, and it was compared to 29 samples on regions of non-incumbent candidates.

From the descriptive explanation above, it can be seen that the mean of social aid expenditure for the incumbent candidate's area was greater than the non-incumbent candidate's sample area when the election was held. Whether the difference is statistically significant or not, the researcher has tested the hypothesis. The results of hypothesis 4 (four) testing are presented in the following Table 5.

Table 5 Hypothesis Testing Result 4

\begin{tabular}{lllllll}
\hline $\begin{array}{l}\text { Mean Log } \\
2016\end{array}$ & Incumbent & $\begin{array}{l}\text { Non- } \\
\text { incumbent }\end{array}$ & Difference & t-count & t-table & Explanation \\
\hline $\begin{array}{l}\text { Grant } \\
\text { Expenditure }\end{array}$ & 4.6992 & 4.5652 & 0.134 & 2.295 & 1.671 & Accept $\mathrm{H}_{1}$ \\
\hline
\end{tabular}

From Table 5, statistically, the average social aid expenditure for the incumbent candidate's area was greater than the non-incumbent candidate's area at the time of the election. The results of this study also strengthen the evidence of an indication of the utilization of social aid expenditure by incumbent pairs for personal political interests during the 2017 elections. This study's results are in line with the results of the study (Ritonga and Alam, 2010; Sjahrir et al., 2013).

The results of this study were also strengthened by the results of the simultaneous election vote calculation on February 15th, 2017, in which from 53 incumbent candidates who participated simultaneously, 32 or $60,37 \%$ incumbent candidates were re-elected as regional heads, consisting of 24 incumbent regents and eight regents mayor's incumbent, while 18 incumbent candidates and three incumbent candidates' areas were re-elected until the time of research data collection the final results have not yet come out (kpu.go.id, 2017).

\section{Conclusion}

The results of hypothesis testing in this study showed empirical evidence that there was an indication of the use of grant expenditure and social aid expenditure by incumbent candidates for political interests so that they could be re-elected during the simultaneous election on February $15^{\text {th }}$ 2017. The results of this study imply that changes in regulations are required, especially the regulation of the Minister of Home Affairs in terms of grant expenditure and social aid expenditure, where these expenditures are no longer included in the indirect expenditure group, but instead belong to the direct expenditure group associated with local government's programs and activities so that then performance can be measured. The purpose of this change is that the grant expenditure and social aid expenditure can no longer be used subjectively, or to reduce the opportunity for incumbent candidates to use these expenditures for their political interests during the election. 
This study has a limitation, which lies in grant expenditure and social aid expenditure studied that only looked at the increase or decrease in the number of realization of grant expenditure and social aid expenditure in the local government budget realization report. This study did not consider whether the grant expenditures and social aid expenditures issued mainly by the incumbent candidates are right on target or not. Suggestions for the next researchers who are interested in conducting research grant expenditures and social aid expenditures during the election in the incumbent candidate's area are that in conducting research not only to see the number of budget realization figures but also tracing the use of grant expenditure funds and social aid expenditure to an appropriate target recipient or not. This search is carried out to determine whether the expenditure is really to help the community or for the political interests of the incumbent candidates or not.

\section{References}

Amalia, C. R., \& Pratolo, S. (2013). Analisis terhadap Dugaan Pemanfaatan Belanja Hibah, Belanja Bantuan Sosial dan Belanja Bantuan Keuangan Oleh Incumbent dalam Pemilukada Serta Efektivitasnya terhadap Pendapatan Asli Daerah. Journal of Accounting \& Investment, 14(1), 1-13. Retrieved from https://journal.umy.ac.id/index.php/ai/article/view/492

Directorate General of Fiscal Balance of Republic of Indonesia Ministry of Finance (2017). After FY of 2006. Retrieved from http://www.djpk.depkeu.go.id/?page id=316

Fatoni, U. (2006). Authority and Legitimacy, Course Material of Introduction to Political Science. Retrieved from http://pengantarilmupolitik.blogspot.co.id/2006/03/kewenangan-dan-legitimasi.html

General Election Commissions Republic of Indonesia (2017). Elected Candidate Pairs. Retrieved from https://pilkada2017.kpu.go.id/pemenang

General Election Commissions Republic of Indonesia (2017). Report of the Candidate Pairs Establishment Stage. Retrieved from https://pilkada2017.kpu.go.id/paslon/tahapPenetapan

Harsasto, P. (2014). Politik Siklus Anggaran Lokal (Studi APBD Kota Surakarta Menjelang Pilkada 2010). Politika, 5(1). Retrieved from http://www.ejournal.undip.ac.id/index.php/politika/article/download/8219/6740

Hessami, Z. (2013). Corruption, Public Procurement, and the Budget Composition: Theory and Evidence from OECD Countries. Working Paper Series, University of Konstanz Department of Economic. Retrieved from http://www.unikonstanz.de/FuF/wiwi/workingpaperseries/WP 27-Hessami 2013.pdf

Kanji, G. K. (1993). 100 Statistical Test. London: SAGE Publication.

Kompas.com (2016). Be Aware of Grant Expenditure and Social Aids Expenditure Abuse. Retrieved from http://nasional.kompas.com/read/2016/09/30/21254331/waspadai.penyimpangan.d ana.hibah.dan.bansos

Mardiasmo (2009). Akuntansi Sektor Publik. Yogyakarta: Andi Publisher.

Republic of Indonesia. (2006). Regulation of Minister of Home Affairs No. 13 in the Year of 2006 About Guidelines on Regional Financial Management. Jakarta: Government of Indonesia. 
Local Election in 2017 in Indonesia: Test of Tendencies to Abuse Grant Expenditure ...

Republic of Indonesia. (2011). Regulation of Minister of Home Affairs No. 32 in the Year of 2011 About Guidelines for Grant and Social Aids sourced from the Expenditure Budget and Regional Revenue. Jakarta: Government of Indonesia.

Republic of Indonesia. (2012). Regulation of Minister of Home Affairs No. 39 in the Year of 2012 About Amendment to the Regulation of the Minister of Home Affairs No. 32 in the Year of 2011 About Guidelines for Grant and Social Aids sourced from the Expenditure Budget and Regional Revenue. Jakarta: Government of Indonesia.

Republic of Indonesia. (2014). Constitution No. 23 in the Year of 2014 About Local Government. Jakarta: Government of Indonesia.

Republic of Indonesia. (2015). Constitution No. 8 in the Year of 2015 About Amendment to Constitution No. 1 in the Year of 2015 About Establishment of Government Regulation in Lieu of Law No. 1 in the Year of 2014 About The Election of Governors, Heads of District and Mayors Becomes the Constitution. Jakarta: Government of Indonesia.

Republic of Indonesia. (2015). Regulation of Minister of Home Affairs No. 52 in the Year of 2015 About Guidelines of Income Budgeting and Regional Expenditure 2016. Jakarta: Government of Indonesia.

Ritonga, I. T., \& Alam, M. I. (2010). Apakah Incumbent Memanfaatkan Anggaran Pendapatan dan Belanja Daerah (APBD) untuk Mencalonkan Kembali Dalam Pemilihan Umum Kepala Daerah. Simposium Nasional Akuntansi XIII Purwokerto. Retrieved from https: $/ /$ www.google.com/url? sa $=t \& r c t=i \& q=\& e s r c=s \&$ source $=$ web\&cd $=\& c a d=$ rja $\underline{\text { \&uact }}=8 \&$ ved $=2$ ahUKEwj9heesgPHpAhWMX30KHewABB4QFjAAegQIAhAB\&u $\mathrm{rl}=\mathrm{http} \% 3 \mathrm{~A} \% 2 \mathrm{~F} \% 2 \mathrm{Fstiepena.ac.id} \% 2 \mathrm{Fwp}-$ content $\% 2$ Fuploads $\% 2 F 2011 \% 2 F 11 \% 2 F A S P \quad 05$.pdf\&usg=AOvVaw3TNPrTDLVsR rN3TSN1XI

Rubin, I. S. (2017). The Politics of Public Budgeting: Getting and spending, Borrowing and Balancing 8th. SAGE Publications, Inc.

Siegel, S. (1956). Non Parametric Statistics for the behavioral Sciences. New York: McGraw-Hill.

Sjahrir, B. S., Kis-Katos, K. \& Schulze, G. G. (2013). Political Budget Cycle in Local Indonesia. Retrieved from https://www.southeastasianstudies.unifreiburg.de/content/files/occasional-peper-series/op-17-kis-katos sjahrir schulze.pdf

Soedibjo, B. S. (2013). Pengantar Metode Penelitian. Bandung: Universitas Nasional PASIM.

Suchman, M. C. (1995). Managing legitimacy: Strategic and Institutional Approaches. The Academy of Management Review, 20(3), 571-610. https://doi.org/10.2307/258788

Suranta, S. \& Pangarso, R. (2015). Budgeting of Social Aids Expenditure and Grant Expenditure Before and During the 2015 General Election of Regional Heads. Prosiding Seminar Nasional \& Call For Paper (SCA 9). Retrieved from http://ip.feb.unsoed.ac.id/index.php/sca-1/article/viewFile/801/23

Winoto, A. H. \& Falikhatun (2015). Indikasi Penyalahgunaan Discretionary Fund Dalam Anggaran Pendapatan dan Belanja Daerah Menjelang Pemilukada 2015. Jurnal Akuntansi dan Keuangan Indonesia, 12(1), 75-79. http://dx.doi.org/10.21002/jaki.2015.05

Yamane, T. (1967). Elementary Sampling Theory. Englewood Cliffs, N.J. Prentice-Hall, Inc. 